\title{
Comparative Analysis of Road Financing Approaches in Europe and the United States
}

\author{
Juan Gomez and José Manuel Vassallo
}

\begin{abstract}
Road infrastructure has a remarkable economic and social impact on society. This is why road financing has always drawn the attention of policymakers, especially when resources available for government spending become scarce. Nations exhibit differing approaches to dealing with road transportation financing. In the United States, the current system of road funding has been called into question because some regard it as insufficient to meet the amounts now required for road expenditures. By contrast, in most European countries, road charges are very high, but these revenues are not allocated for the funding of roads. This paper analyzes the balance between charging for the use of and expenditure on the road sector in the United States and compares the American policy with those of sevcral European countries (Germany, United Kingdom, France, Spain, and Switzerland). To that end, a methodology is defined to calculate the annual amount of fee charges levied on light and heavy vehicles in the selected countries in order to compare those charges wilh annual road expenditures. The results show that road charges in America are noticeably lower than those paid in Europe. Additionally, the research concludes that in Europe, road-generated revenues exceed road expenditures in all the countries studied, so road charges actually subsidize other policies. By contrast, in the Lnited States, the public sector subsidizes the toad system in order to maintain the current level of expenditure.
\end{abstract}

Author keywords: Road funding; Roacl financing; Road taxation; United States; Europe; Gas tax.

\section{Introduction}

Surface transportation infrastructure substantially contributes to economic growth, improves national productivity, and promotes regional development (Sundeen and Reed 2006). For this reason, transportation financing has always been a crucial aspect of policy for public transportation agencies. The importance and complexity of road financing has grown in the last few decades due to the increasing shortage of revenues, which has led to budgetary constraints in many governments (Szimba and Rothengatter 2012) and made the proper allocation of the limited resources available to road purposes even more critical.

Road-funding approaches vary substantially across different nations. In the United States, the present road funding model is being questioned because it has proved insufficient to meet the investment needs of current programs. To address this shortfall, both short- and long-term measures are being considered. These include both raising the federal fuel tax, unchanged since 1993, and promoting a gradual transition toward a vehicle-mileage-traveled (VMT) fee. However, these measures have met with both social and political resistance.

On the other hand, European countries are now facing serious budgetary constraints as a result of the economic recession. This fact is limiting their resources to fund roads. With the objective of providing stable revenue sources for road funding and promoting a more sustainable transportation system within Europe, some countries have implemented road pricing approaches that would include charges on heavy goods vehicles in certain sections of their interurban roads.

The aim of this paper is to quantify the annual revenues generated by road transport charges (tolls, fuel taxes, and other fees) in the United States and several European countries in order to compare them with their respective annual levels of road expenditure (RE). This comparison is directed toward an analysis of simitarities and differences among national policies to evaluate the impact of different funding approaches in road expenditure levels. For this purpose, a large amount of information from official sources has been collected, sometimes with data limitations. The approach described here, that of comparing U.S. and European road-funding approaches, represents the first time such an approach has been taken and thus constitutes a new contribution to the literature on transportation financing. The paper also seeks to draw conclusions about the funding system in the countries selected and to lay out several implications for policymakers.

The paper is organized as follows. Following the introduction, the state of knowledge regarding road funding in the United States and Europe is summarized, and previous research dealing with the revenue-expenditure balance in the road sector is described. The next section establishes the methodology of this research, and then. results are presented. Finatly, the main conclusions and policy implications are set out.

\section{Road Funding in the United States and Europe}

This section presents the state of knowledge of road funding. It is divided into three subsections. In the first two subsections the most specific features of road financing are described in the United States and Europe, respectively. In the third subsection, previous studies dealing with revenue-expenditure balance in road networks are summarized. 


\section{Moad Funding in the United States}

Most of the resources for funding highways in the United States comes from fees paid by those who use the road network, in the form of, for example, fuel taxes, tolls, vehicle excise taxes, tire taxes, truck and trailer sales taxes, and heavy vehicle use taxes. Consequently, the U.S. model is chatacterized by a strong connection between road revenues and expenditures. The suitability of limiting highway reverues to road purposes has been widely discussed, with opinions both in favor of and against the measure (Wachs 2003). State and local governments do collect revenue from a variety of charges, and not only specifically targeted ones, and these include the general taxes on the population (income, sales, property) unrelated to motor vehicle use (Delucchi 2007). The increasing use of general taxes to fund transportation programs at the state and local levels breaks the links associated with the traditional "user pays" concept (Downs 2005).

Historically, fuel taxes-majnly federal and state ones-have played a crucial role as the primary source for funding highways in the United States. However, the viability of the current system of highway funding, even in the short term, has in recent years been widely questioned in the literature [Wachs 2003; Cambridge Systematics and Pisarski 2005; Whitty 2007; National Sutface Transportation Policy and Revenue Study Commission (NSTPRSC) 2007; National Surface Transportation Infrastructure Financing Commission (NSTIFC) 2009]. Present revenues at all governmental tevels - federal, state, and local-turto out to be insufficient to support spending programs for highways and roads at their current level. In fact, at the federal level, some transfers from the general fund have been needed since 2008 to keep the Highway Trust Fund solvent (NSTIFC 2009; Sorensen et al. 2010; US DOT 20I2).

The crisis in the highway funding model can be partly explained by the significant erosion of fuel tax receipts, as federal rates have remained unchanged since 1993. In addition, the rise in state fuel taxes has not kept pace with inflation [Transportation Research Board (TRB) 2006]. Furthemore, according to estimates from the Federal Highway Administration (FHWA), from 2007 to 2026 total capital spending would need to average $\$ 126$ billion/year to maintain the federal highway system's performance, while actual capital spending is significantly lower [Congressional Budget Office (CBO) 2011]. For all these reasons, it is expected that the current system, which relies primarily on fuel taxes, will not be sustainable in the long term (Oh and Sinha 2011). Fuel consumption and, cousequently, revenues from gas taxes will probably decline noticeably as a result of improvements in fuel efficiency and the progressive penetration of altemative fuels and propulsion systems for motor vehicles (Cambridge Systematics en al. 2012; NSTIFC 2009; Wakeley et al. 2008).

A wide variety of measures to increase revenue have been presented in the literature (Sundeen et al. 2006; Standing Committee on Financing and Administration 2007; NSTIFC 2009). In the short term, it has been proposed to raise fuel taxes, at least to increase them so as to keep pace with inflation. Other suggestions include extending the use of toll highways, levying new taxes and fees, and encouraging the use of public private partnerships (PPPs), though the United States remains a relatjvely slow mover in this market (Garvin 2010). In the long term, a VMT fee has been identified as the most suitable option (Goodin et al. 2009) because it could constitute a reliable source of lunding, reduce traffic congestion, and promote a more efficient use of vehicles. However, implementing a distance-based pricing scheme faces several challenges regarding, for example, financial feasibility, technology, administration, and public and political acceptance ( $\mathrm{Oh}$ and Sinha 2011). To assess the feasibility of a VMT fee, studies and pilot projects have been developed in the last few years in places such as Oregon and lowa. However, there is still a consensus that fuel taxes should remain as the main source of revenues for the Highway Trust Fund until viable alternatives are found (NSTPRSC 2007; TRB 2006).

\section{European Countries}

European countries have adopted a different approach to road funding. Unlike the Uniled States, gas tax revenues are rarely dedicated to the funding of REs. They are, rather, considered as part of the general revenues and allocated to the general budget, so their final application is ultimately decided by the Parliament. The UK government, for instance, is in favor of implementing high, but non-road-allocated, gas taxes as a means for the government to collect revenues for use in dealing with public policy priorities, and that includes some that are clearly transportation-related, such as reducing air pollution and traffic congestion (Parry and Small 2005). As happens in the United States, fuel taxes in Europe represent one of the most important road user charges.

European countries are now facing serjous budgetary constraints as a result of the economic recession. In some cases it has caused severe changes in road management. In Portugal, for instance, some of the former shadow toll road sections shifted toward real toll schemes because of governmental rovenue needs (Cruz and Marques 2013). In the last few years, budgetary limitations have led European governments to explore new mechanisms to fund road expenditures.

The implementation of distance-based tolls in Europe is usually associated with the private operation of roads through concession contracts. Countries such as France, Spain, and Italy have an extensive toll road network (more than $20 \%$ of total trunk bighways) run mostly by private concessionaires. Naturally these tolls are allocated to finance road expenses. Other European countries, however, have implemented time-based flat fees (known as vignettes), which allow users to drive during a specified period of time (day, week, month, year). Some countries, such as Belgium, the Netherlands, and Sweden, apply vignettes to heavy vehicles. Other nations, such as Switzerland, Austria, and the Czech Republic, apply vignettes to light veliches. Vignettes are usually collected by public road agencies and are often allocated to fund road infrastructure needs.

Ever since the approval of the road charging Directive 1999/62/ CE (European Parlianent 1999), the European Commission (EC) has been promoting the implementation of a harmonized approach of distance-based tolks on heavy goods vehicles (or heavy-vehicle fees, HVF) in specified sections of the nonprivatized network. This approach belongs to a wider transport policy strategy intended to achieve both a more sustainable transport system by promoting cleaner vehicles and a more stable mechanism for funding roads as distance-based charges on heavy vehicles are usually allocated to road purposes. Following the tirning furst envisioned by the European Union (EU), several nations (Austria and Germany, among others) a few years ago established distance-based tolls on heavy vehicles, mainly in the whole trunk highway network or specific sections of it, white other nations (e.g., Poland and Slovakia) have more recently adopted the system or are expected to do so soon (France) in their nonprivatized high-capacity network.

In addition, European countries apply some charges to road users (e.g., vehicle purchase, vehicle ownership, plate fees), and the resulting revenues are very rarely allocated to road purposes.

\section{Previous Studies}

Economic balances in road transport networks have becn the subject of several studies in recent decades. MacKenzie et al. (1992). 
analyzed data in the United States from 1989 and concluded that payments by highway users fell short of public expenditure on roads, including, for example, capital outlays, maintenance, and highway services. Similarly, Morris and DeCicco (1997) found that revenue from road user fees covered only $78 \%$ of public roadrelated costs, with a gap of $\$ 21.7$ billion in 1992 . Later, the FHWA (1997) estimated that the ratio of highway user fees to highwayrelated expenditure for all levels of government would be about 0.8 by fiscal year 2000 . On the other hand, focusing on external costs, Greene et al. (1997) compared social costs caused by transport with benefits for, and receipts from, users.

More recently, Link (2005) presented the results of the UNITE project, covering road, rail, and air transportation for the entire EU and Switzerland. She calculated both the total road costs (infrastructure, external, and accident costs) and the road revenues for 1998 and concluded that it was desirable, and even necessary, to establish a closer link between charge rates, road costs, and the use of resources. Delucchi (2007) compared expenditures and payments in the United States in 2002 using four different ways of accounting. He concluded that tax and fee payments fell short of government expenditures on roads, and consequently motor vehicle users in the United States did not "pay their way."

Some studies have assessed different aspects regarding the implementation of a VMT fee in the United States. Oh et al. (2011) developed a distance-based highway pricing scheme as an alternative to the current taxation of motor fuels. McMullen et al. (2010) analyzed distributional impacts-by income and location-that would result from the replacement of the current fuel tax in Oregon with a revenue-neutral flat VMT fee. Finally, Bertini and Rufolo (2004) presented alternative technologies and other business options for the collection of distance-based user fees.

As can be seen, a direct comparison of American and European approaches for funding roads has never been conducted in the literature. The main objective of this paper is precisely to fill this research gap and to update previous analyses of road-funding and transportation policy in both Europe and the United States.

\section{Methodology}

This paper calculates the balance between road-generated revenue and RE in the United States and several European countries from 2004 to 2009. Five European nations (Germany, France, the U.K., Spain, and Switzerland) have been included in the analysis. The first four countries in the sample are among the biggest EU economies, whereas Switzerland, not a member country of the EU, is an interesting case since the level of road charges applied to road users is likely the highest in the world. Despite its limited size, the sample attempts to present some variety since the countries selected have different characteristics in terms of, for example, area, population, GDP, location on the continent, and road-funding sources. Other additional European nations were considered but in the end not included in the analysis due to unavailability of data.

The analysis includes the whole interurban network (federal, state/regional, and local) as identified in the records of each country. The sample has also tried to include countries with different interurban road management approaches in Europe. Germany presents the example of an extensive high-capacity network, mainly managed and operated by the public sector, alongside a network of conventional roads. The same occurs in Switzerland, with a high presence of governmental offices or public agencies in the interurban road infrastructure. In France, around $75 \%$ of high-capacity roads are tolled and operated by concessionaires, while the rest of the interurban network is managed by the public sector and financed through public budgets. Excluding specific tolled sections (bridges, tunnels), users are not required to pay when driving in interurban roads in the U.K. because they are generally operated by private companies through shadow toll schemes. Finally, the case of Spain offers a combination of a variety of approachestolled highways (nearly $20 \%$ of high capacity roads), shadow toll sections, and roads managed by the public sector.

The methodology for this research required two steps. In Step 1 the revenue versus expenditure balance of the road sector in the period 2004-2009 is shown. In Step 2 the road charges paid by three types of vehicles (gasoline light vehicle, diesel light vehicle, and heavy vehicle) are compared in each of the countries in the sample. Further methodological details of this research can be found in Gomez (2012).

\section{Step 1: Revenue versus Expenditure Balance}

This step calculates the difference between RE and road-generated revenue (RGR) across the selected countries. For this purpose, a great amount of data has been collected from official government sources: ministries, departments, institutes, national statistics services, and others. The appendix includes the main documents and institutions relied on for this research.

The RE incorporates the items described in Table 1. Annual expenditure includes both capital outlays and maintenance costs, per year, for both roads supported by different levels of government and private roads (which depend for revenues on PPPs, that is, mainly concession contracts). Other items, such as, for example, traffic management expenditure, administration, enforcement, and interest on debt, are not included as data were not available in a similar and, therefore, comparable form for all of the countries in the sample.

The RGR term incorporates the items summarized in Table 1. RGR includes all kinds of fee-charges applied to road users, regardless of whether they are dedicated to the funding of roads or not. Taxes, such as fuel taxes, which are applicable in a special way to road vehicles, are also included within RGR. Taxes that are applied in a fairly homogeneous way across different economic sectors, such as value added taxes, are not included within RGR.

In Step 1, the percentage of RGR that is allocated to roadfunding purposes is also analyzed. This results from calculating the ratio between allocated revenue (AR) and RGR. Allocated revenue is defined as the annual revenue that is directly dedicated to funding roads in general, without taking into account whether or not it is dedicated to specific road projects. For the calculation of AR, it is assumed the simplification that all the revenue from tolls is devoted to funding roads despite the fact that this is not

Table 1. Items Included as Road Expenditure and Road-Generated Revenue

\begin{tabular}{|c|c|c|}
\hline Concept & Road expenditure (RE) & $\begin{array}{l}\text { Road-generated } \\
\text { revenue (RGR) }\end{array}$ \\
\hline \multirow[t]{4}{*}{ Items included } & Public capital outlays & $\begin{array}{l}\text { Fuel tax } \\
\text { Public tolls }\end{array}$ \\
\hline & Private capital outlays & $\begin{array}{l}\text { Private tolls } \\
\text { Vignettes }\end{array}$ \\
\hline & $\begin{array}{l}\text { Public maintenance } \\
\text { disbursements }\end{array}$ & $\begin{array}{c}\text { Heavy-vehicle fee } \\
\text { (Eurovignette) } \\
\text { Vehicle excise duties: } \\
\text { e.g., vehicle ownership fee, } \\
\text { registration fee, purchase fee }\end{array}$ \\
\hline & $\begin{array}{l}\text { Private maintenance } \\
\text { disbursements }\end{array}$ & $\begin{array}{l}\text { Other vehicle fees } \\
\text { Company car taxation }\end{array}$ \\
\hline
\end{tabular}


always the case. For instance, the privatization of the Indiana toll road in the United States implied that tolls were used to pay the state of Indiana. In addition, gas taxes and other fees are considered part of the AR insofar as the national legislation allocates them to fund roads. As a result, AR is obtained by adding revenue from tolls and revenue allocated for road funding by legislation.

The analysis conducted in this research establishes a balance between charging for the use of, and expenditure on, the road sector alone. For the purpose of this paper RGR allocated to other usesas happens with RGR allocated to public transport in the United States or to railway projects in Switzerland-is not accounted for within the road sector balance.

Making calculations for the United States is not an easy task since every state and county has its own taxes imposed within its own jurisdiction and uses different criteria in allocating these taxes to road funding. Due to the arduous effort needed for collecting this information, calculation of the AR does not include the allocation of these taxes. However, state fuel taxes are included because they are a primary revenue source for states, and information about how they are allocated is easy to collect. The analysis includes fuel tax receipts from states that restrict, through either constitutional or statutory provisions, the application of such revenues to road purposes, as set out in Rall et al. (2011). Therefore, the AR must be considered as a minimum reference value since the real figure will surely be higher after including the specifics of state and local legislation.

After briefly describing the methodology adopted for the revenue versus expenditure balance, comments need to be made. Current analysis compares RE and RGR in the road sector but does not take into account any social costs. The existence of a road system has negative impacts - e.g., air and noise pollution, congestion-as well as great indirect benefits, such as, for example, accessibility improvements, regional development, and increases in land prices, that are not included in the calculation of this economic balance.

Finally, with the data available, several ratios are calculated for each nation per year. A description of these ratios and analysis of the results are shown later.

\section{Step 2: Annual Charges Pald Per Driver}

In Step 2 a comparison is made of charges applied to three types of vehicles across the countries selected for the sample. Three types of vehicles are included in this analysis: gasoline light vehicle, diesel light vehicle, and heavy vehicle. The characteristics of the type of vehicles are described in Table 2 . The rates according to what was imposed as of January 1, 2012, on these vehicles are applied.

In this step, types of vehicle are defined in order to make a homogeneous transnational comparison of the charges paid by drivers in each nation controlling for variables-such as, for example, annual mileage and fuel consumption — which might be different in each country. The type-of-vehicle approach is not intended to reflect a hypothetical "average vehicle" in either the United States

Table 2. Main Characteristics of Vehicle Type Considered in Analysis

\begin{tabular}{lccc}
\hline & \multicolumn{2}{c}{ Light vehicle } & \\
\cline { 2 - 3 } Concept & Gasoline & Diesel & Heavy vehicle \\
\hline Annual mileage $(\mathrm{km})$ & 20,000 & 20,000 & 95,000 \\
Fuel consumption $(\mathrm{L} / 100 \mathrm{~km})$ & 6.7 & 5.3 & 28.0 \\
Power (horsepower) & 115 & 116 & 350 \\
Vehicle weight (ton) & 1.2 & 1.2 & 10.0 \\
Maximum weight (ton) & $\mathrm{NA}$ & $\mathrm{NA}$ & 26.0 \\
Life (years) & 10 & 10 & 10 \\
\hline
\end{tabular}

Note: NA = not applicable. or Europe. Rather, it is meant to show the charging differences across different countries in a way that allows for easy and homogeneous comparison.

In what follows are shown the most relevant features of the methodology adopted to allocate charges to the three distinct types of vehicle.

- As was done in Step 1, only user charges eligible for RGRs, as set out in Table 1, are shown.

- Most of the road charges, such as fuel taxes and tolls, are paid each time drivers use their cars. Other charges, such as vehicleownership fees, are paid once a year. Still other charges, such as the tax on vehicle purchases, are paid only once during the life of the vehicle. To properly convey the yearly cost of this tax, the total amount of the tax is divided by the expected life of the purchased vehicle.

- Noticeable differences in fee-charges can be found in different regions and states within the same country. Because the type-ofvehicle methodology is used to give a representative view, average national values are calculated.

- In the United States, great variability in road fees in different states and even in different counties is observed. For this reason, several state DOTs were asked to supply figures for road taxation.

- National road networks are made up of both tolled and free sections. With the aim of providing a representative figure, the percentage of total road use that consisted of toll roads in the countries that form the study's sample was calculated and applied to the annual mileage corresponding to each of the three types of vehicle.

- Toll rates can vary, even within the same country, depending on the particular stretch of road. For European countries, average rates calculated from official data were adopted. In the United States, because average rates in the American toll road network are not provided by official sources, selected rates (converted to dollars per vehicle-kilometer) from the Kansas Turnpike network were adopted, after the authors checked and assured themselves that similar values were applied in other states, e.g., Oklahoma and Florida.

\section{Results and Comments}

This section summarizes the main findings from the analysis developed in Steps 1 and 2. Regarding Step 1, with the data collected from national sources, three ratios were calculated: the expenditure/ revenue ratio, the expenditure/GDP ratio, and the road allocation ratio. Again, further details can be found in Gomez (2012).

As can be seen in the "Methodology", some data limitations have been found when collecting information from official sources, such as, for example, heterogeneity regarding concepts, disaggregation in road accounts, lack of average values in certain areas, great variety of road-funding approaches at regional, state, and local levels. Therefore, the study findings should be taken as good approximations of the true values rather than exact ones.

The expenditure/revenue ratio shows the money spent on roads per dollar levied. It can be easily obtained after dividing RE by total RGR:

$$
\text { Expenditure/revenue_ratio }=\frac{\mathrm{RE}}{\mathrm{RGR}}
$$

Fig. 1 shows the results of the expenditure/revenue ratio for the period 2004-2009. Three groups of countries emerge: first, nations with a strong dedication of revenues to road purposes (the United States and Switzerland), with more than $80 \%$ of revenues so 


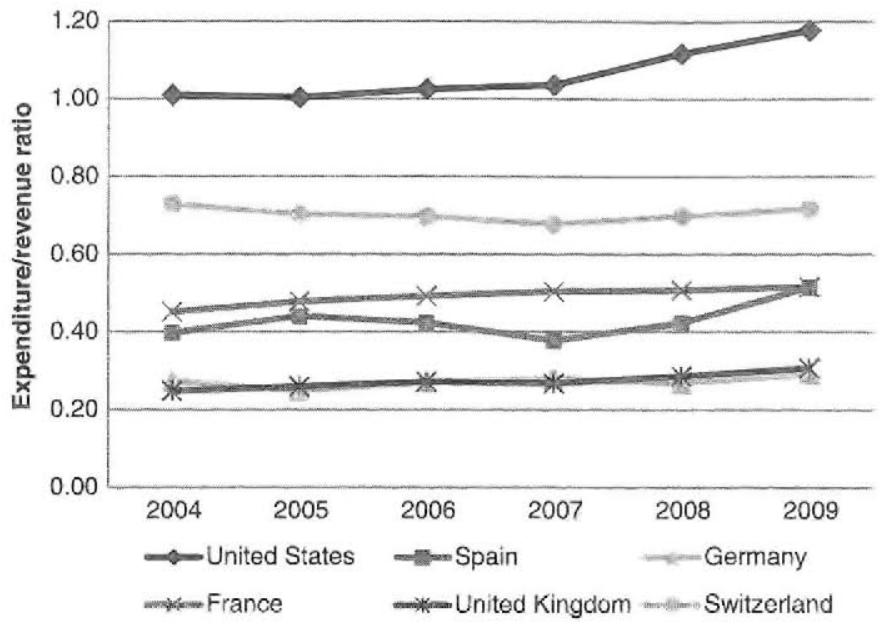

Fig. 1. Expenditure/revenue ratio for selected countries

dedicated; second, nations with medium dedication (France and Spain), of around 40-50\%; and third, nations with low levels of dedication of revenues (Germany and the U.K.), corresponding to percentages around $30 \%$ or below. As can be seen in the figure, excluding the United States and Spain, the ratios have remained relatively constant throughout the years.

Apart from Switzerland, which is an exception because of its extremely high level of road charges, some common features about American and European road funding models can be identified. Fig. 1 shows that for European governments RGR greatly exceeds $\mathrm{RE}$; this means that road transport revenues are being used to fund other government policies. By contrast, the U.S. road system has needed additional funds from general taxation to fund roads in the selected period, and especially after fiscal year (FY) 2007. Then, the expenditure/revenue ratio rose noticeably, moving from 1.04 in 2007 to 1.18 in 2009 . This was caused by two main effects: first, a slight decrease in revenues, from $\$ 122.4$ billion in 2007 to $\$ 118.9$ billion in $2009(-2.8 \%)$, partly influenced by the deterioration of the economic environment and traffic reductions due to rises in fuel prices; and second, a significant increase in road expenditure from $\$ 126.8$ billion in 2007 to $\$ 140.1$ billion in $2009(+10.5 \%)$. The trend shown in Fig. 1 explains the existing concern in the United States about the road-funding issue. In fact, some authors noted that, since FY2008, the Highway Trust Fund has received a total of $\$ 34.5$ billion in general fund transfers to maintain its solvency (US DoT 2012; CBO 2012). To sum up, one can make the observation that, whereas in Europe the road system subsidizes other government policies, roads in the United States are subsidized by the public through general taxation.

The analysis includes the calculation of the expenditure/GDP ratio, showing the effort made by each nation in terms of $\mathrm{RE}$ as compared to national GDP:

$$
\text { Expenditure/GDP_ratio }=\frac{\text { RE }}{\text { National_GDP }}
$$

Results for this ratio are shown in Fig. 2. Switzerland has the highest ratio, with a level of expenditure around $1.4 \%$ of its GDP. This is likely a consequence of the high charges imposed by Switzerland and the high $R A$ ratio of the country, as will be shown in greater detail later. The other countries in the sample exhibit an expenditure on road transport between 0.5 and $1.0 \%$ of their GDPs. The rise in this ratio found in Spain and the U.K. since 2007 is explained by GDP reductions rather than by increases in road expenditures. The ratios for France and Germany have remained

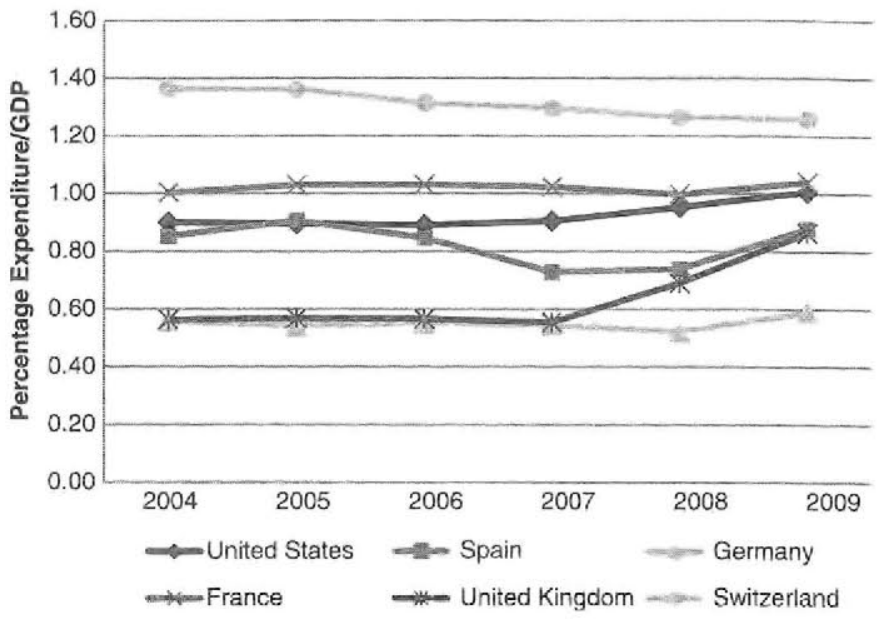

Fig. 2. Road expenditure/GDP ratio for selected countries

stable over the years, whereas the United States experienced an increase from $0.90 \%$ of GDP in 2007 to $1.01 \%$ in 2009 . It is important to note that the most suitable ratio in each country is not necessarily comparable since it might vary according to, for example, national population, area, or density of population.

An analysis of the revenue allocated to road purposes was also conducted. To that end, the road allocation ratio was calculated according to Eq. (3). This ratio shows the share of RGR dedicated to road purposes. It can be obtained by dividing AR by RGR:

$$
\text { Road_Allocation_ratio }=\frac{\mathrm{AR}}{\mathrm{RGR}}
$$

Fig. 3 shows the results obtained for the road allocation ratio. The United States, which allocates both federal and part of state taxes, has the highest ratio, approximately 0.50 . However, as was mentioned in the "Methodology", this ratio must be considered as a minimum value because no allocation of revenue to roads was considered, apart from state fuel taxes, at the state or local level. Switzerland is in second place, with a ratio of around 0.44 , as a large amount of its RGR (vignette, fuel tax, and heavy vehicle fee) is allocated to road-funding proposes. France and Spain have ratios of between 0.2 and 0.1 because the only revenues dedicated in these countries are private tolls. Germany and the U.K. have even lower values, even though Germany has seen this ratio increased in

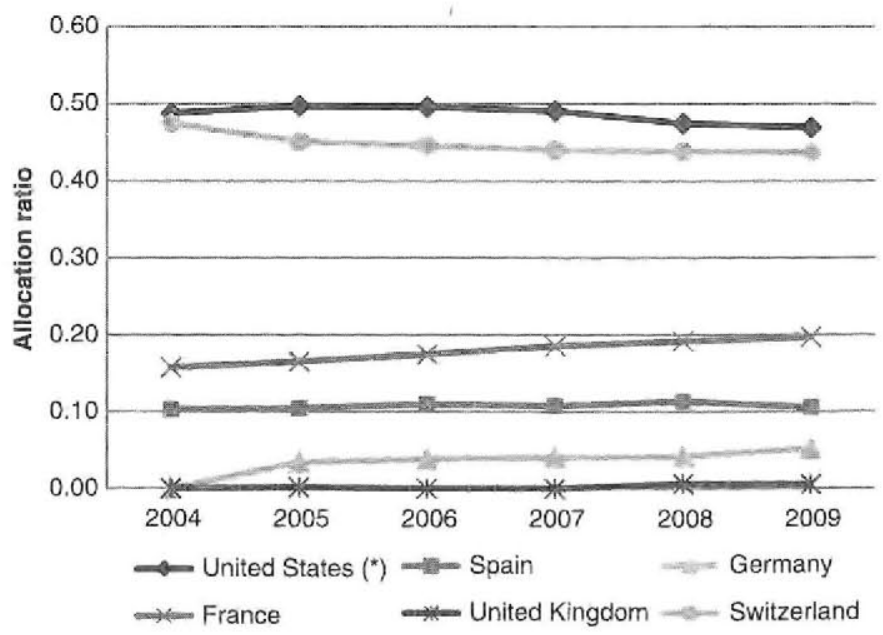

Fig. 3. Road allocation ratio for selected countries 


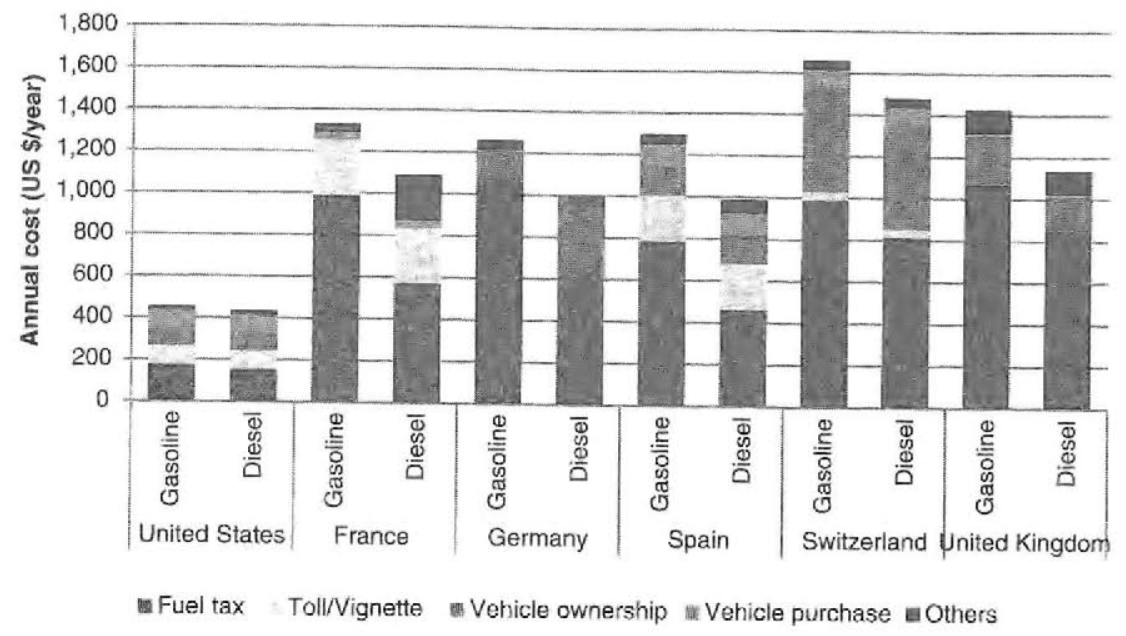

Fig. 4. Annual specific road charges paid by type of light vehicle adopted in 2012

the last few years due to the implementation of charges for heavy goods vehicles partially dedicated to road financing.

Taking Figs. 2 and 3 together, and analyzing their contents, it can be observed that, despite the small size of the sample, the higher the road allocation ratio the higher seems to be the level of RE to GDP.

It is also interesting to consider whether there is any correlation between the results calculated and private sector participation in road management. In light of Figs. 1-3, it does not seem that trends concerning private sector involvement can be clearly discerned. For instance, Germany and Switzerland show radically different results, even though the road network in both cases is mainly managed and operated by the public sector. On the other hand, results seem actually to be highly dependent on the level and allocation of revenues from fuel taxes and on the implementation of pay-per-use mechanisms.

To make the previous analysis more comprehensible, results from Step 2 of the methodology are displayed in Figs. 4 and 5. They show the annual charges levied on light and heavy type vehicles, respectively, as defined in the methodology. Despite

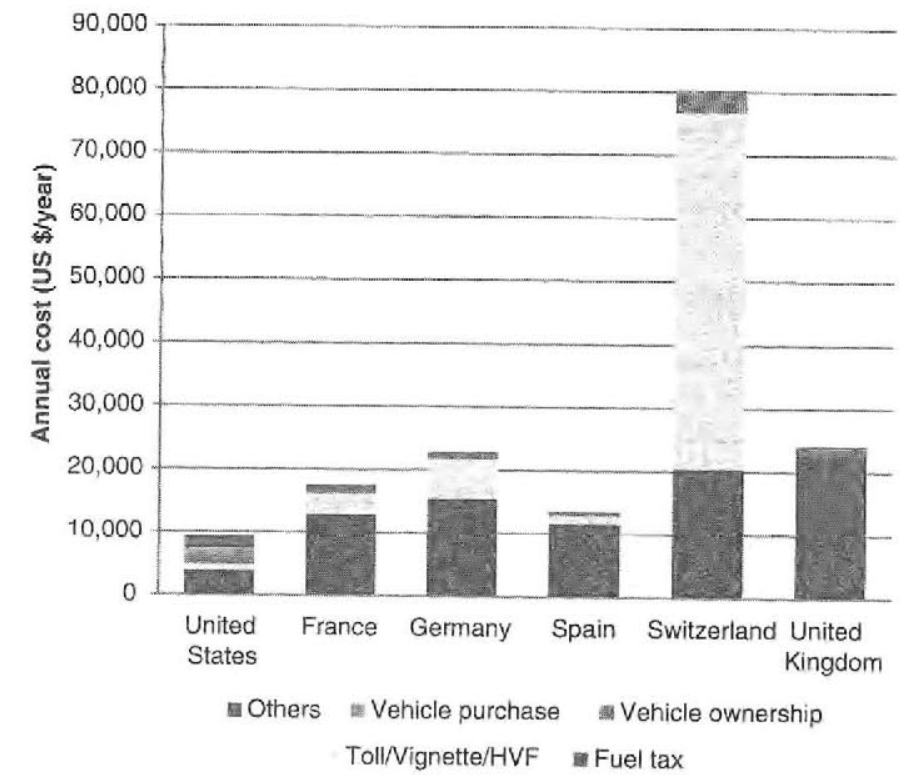

Fig. 5. Annual specific road charges paid by type of heavy vehicle adopted in 2012 differences among nations, we observed that road charges in the United States are noticeably lower than those in European countries.

With regard to light vehicles Fig. 4 shows a comparison of the charges in the United States and in the European countries. Differences in the sample ranged from 2.7 to 3.6 for gasoline vehicles and from 2.2 to 3.4 for diesel vehicles. The greatest divergences are caused by the low level of fuel tax rates applied in the United States - 77-83\% lower for gasoline vehicles and $66-81 \%$ lower for diesel vehicles-when compared with the selected European countries.

As for heavy vehicles, average annual U.S. charges ranged from being $32 \%$ lower than those in Spain'to $62 \%$ lower than those in the U.K. Switzerland, with a strong policy of heavy-vehicle charging, can be considered a unique case in the world. Again, the main difference between the United States and European countries has to do with the rates of fuel taxes. The importance of tolls in France and heavy-vehicle fees in Germany compared to the United States should also be emphasized. The low levels of road fee charges in the United States compared to European countries seem surprising given its high road-funding needs.

\section{Conclusions}

This paper compared the U.S. road-funding model with that of five European nations. The analysis yielded some interesting conclusions.

The first conclusion is that in the last few decades Europe has been progressively moving toward implementing tolls, especially for heavy goods vehicles, as a means of both enhancing a more sustainable mobility and guaranteeing stable and nonbudgetary resources for funding roads. However, the implementation of these tolls has not been accompanied by a reduction in other road charges, such as fuel or vehicle-ownership taxes. This fact has underscored the role in Europe of road transportation as a revenue source for the general budget. By contrast, the United States has conducted few reforms in its road-funding model over the last few decades. This situation has led the United States to raise scarce revenue to cover the necessary REs.

The second conclusion, which is a consequence of the first, is that European roads subsidize other government policies, whereas U.S. roads must be subsidized by the public through general fiscal revenues. This fact has been striking ever since 2007 because of the rise in road expenditure in the United States, making it necessary, at 
the federal level, to transfer money from the general fund to the HTF. The U.S. funding model has shown itself to have a limited capacity to meet the increasing demands of road programs in the future. In this respect, it seems clear that significantly relying for the securing of funds on nonrevisable or seldom-revisable charges, as happens with the federal gas tax in the United States, makes the system unsustainable in the long term. In addition, general taxes (income, property, sales) play a major role in the road-funding system at the local level, which breaks the reliance on the traditional "user pays" principle. That is why the option of rising existing charges or implementing new ones might be considered.

The third conclusion concerns the low level of road charges ap plied in the United States as compared to the practice in European nations, especially with regard to fuel taxes. Apart from Switzerland, whose high fees can be considered a unique case in the world, the remaining countries in Europe have annual vehicle charges ranging from 127 to $214 \%$ higher than the United States for light vehicles and from 46 to $162 \%$ higher than the United States imposes for heavy vehicles. In spite of the high road allocation ratio of the United States, RGR has not been able to cover RE needs in the last few years. This fact might suggest that the level of road charges in the United States is becoming lower than needed.

Again, the approach of this research is focused on the financial balance of the road system so as to ensure that it does not incorporate any social costs or externalities associated with the road sector. Extending the present analysis would allow capturing both negative and positive externalities related to the road network in order to deternine the social optimum. This could be conducted by estimating the proper amount of funds to be dedicated to, and levied from, the road sector and deciding who should pay, and how much, for the indirect benefits of roads.

From the results of this paper many questions arise. What would be the best way of raising revenue from road-usage: tolls, fuel taxes, others? Is there any economic reason behind cross-subsidies from road transportation to other transportation modes or the general budget? Are users of roads being overcharged in Europe, or are they undercharged in the United States? Future research should explore issues such as the impact of road-charging on a more general sustainability, the impact of cross subsidies from the road to other transportation modes or to other sectors of the economy with lower externalities, and the optimal revenue to be allocated to the road sector given its significant externalities.

\section{Appendix. Summary of Official Sources Relied upon for Collecting Data}

\begin{tabular}{|c|c|c|}
\hline Country & Institution & Document (year) \\
\hline \multirow[t]{4}{*}{$\begin{array}{l}\text { United } \\
\text { States }\end{array}$} & U.S. Census Bureau & $\begin{array}{l}\text { State and local government } \\
\text { finances }(2004-2009)\end{array}$ \\
\hline & Federal Highway & U.S. highway statistics \\
\hline & Administration (FHWA) & $(2004-2009)$ \\
\hline & $\begin{array}{l}\text { National Conference of } \\
\text { State Legislatures (NCSL) }\end{array}$ & $\begin{array}{l}\text { Transportation governance } \\
\text { and finance; a 50-state } \\
\text { review of state legislatures and } \\
\text { departments of transportation } \\
\text { (2011) }\end{array}$ \\
\hline \multirow[t]{3}{*}{ France } & $\begin{array}{l}\text { Commissariat général au } \\
\text { développement durable }\end{array}$ & $\begin{array}{l}\text { Les comptes des transports } \\
(2008-2010)\end{array}$ \\
\hline & $\begin{array}{l}\text { Association professionnelle. } \\
\text { Autoroutes et ouvrages } \\
\text { routiers (ASFA) }\end{array}$ & $\begin{array}{l}\text { Chiffres clés (2007; } \\
\text { 2009-2011) }\end{array}$ \\
\hline & $\begin{array}{l}\text { Ministère de 1'Écologie, } \\
\text { du Développement }\end{array}$ & $\begin{array}{l}\text { Chiffres clés du transport } \\
(2009-2011)\end{array}$ \\
\hline
\end{tabular}

Appendix (Continued.)

\begin{tabular}{ll}
\hline Country & \multicolumn{1}{c}{ Institution } \\
\hline & durable, des Transports \\
& et du Logement \\
& Direction générale des \\
& infrastructures, des \\
& transports et de la Mer \\
Germany & ProMobilität
\end{tabular}

Bundesministerium für Verkehr, Bau und Stadtentwicklung Statistisches Bundesamt

Spain Ministerio de Fomento

Ministerio de Economía y Hacienda

Agencia Tributaria

Switzerland Office Fédéral de la 、 Statistique

Administration Fédéra! des finances

Administration Fédéral des Contributions Administration Féderal des Douanes

United Department for transport Kingdom and national statistics

HM Revenue and Customs and National Statistics

Office for National

Statistics

Macquarie
La fiscalité du transport routier de marchandises en 2011 (2011)

Investionen westeuropäischer Staaten in

Straßeninfrastruktur (2011)

Strassenbaubericht (2004-2010)

Statistisches Jahrbuch 2011 (2011)

Anuario Estadístico

(2005-2010)

El tráfico en las autopistas de peaje (2008-2010) Informe 2009-2010 sobre el sector de autopistas de peaje en España (2011)

Series históricas de la recaudación tributaria del Estado y de las Comunidades Autónomas (2010)

Haciendas locales en cifras (2004-2009)

Las haciendas autonómicas en cifras (2006-2009)

Informe Anual de

Recaudación

Tributaria (2010)

Compte routicr suisse

(2007-2009)

Mobility and transport. pocket statistics (2009-2011)

Transfert des redevances sur la circulation routière vers 1 impôt

sur les huiles minérales (2007)

Impôts sur les véhicules à

moteur (2004)

Impôts et taxes sur le pétrole. Notice per les consommateurs (2011)

Impôts sur les vébicules à moteur (2004)

Transport Statistics

Great Britain

(2006-2011)

Expenses and benefits

statistics (2011)

The blue book (2010)

Macquarie Atlas Roads. Annual Report (2009; 2011)

\section{References}

Bertini, R. L., and Rufolo, A. M. (2004). "Technology considerations for the implementation of a statewide road user fee system." Res. Transp. Econ., 8, 337-361.

Cambridge Systematics, Mercator Advisors, Pisarski, A. E., and Wachs, M. (2012). "Future financing options to meet highway and transit needs." Contractor's final report for NCHRP project 20-24(49), web-only 
document 102, National Cooperative Highway Research Program, Transportation Research Board, Washington, DC.

Cambridge Systematics, Mercator Advisors, and Pisarski, A. E. (2005). "Future highway and public tuansportation finance. Phase I: Current outlook and short-term solutions." Executive Summary, National Chamber Foundation, U.S. Chamber of Commerce, Washington, DC.

Congressional Budget Office. (2011). "Altervative approaches to funding highways." Publication 4090, Washington, DC.

Congressional Budget Office. (2012). "The budget and economic outlook: Fiscal years 2012 to $2022 . "$ Publication 4474, Washington, DC.

Cruz, C. O., and Marques, R. C. (2013). "Risk-sharing in highway concessions: Contractual diversity in Portugal." J. Prof. Issues Eng. Educ. Pract., 10.1061/(ASCE)EI.1943-5541.0000131, 99-108.

Delucchi, M. A. (2007). "Do motor-vehicle users in the US pay their way?" Transp. Res. A Pol. Pract., 41(10), 982-1003.

Downs, T. M. (2005). "Is there a future for the federal sufface transportation program?" J. Transp. Eng., 10.1061/(ASCE)0733-947X(2005)131:6 (393), 393-396.

European Parliament. (1999). "Directive 1999/62/EC of the European Parjiament and of the Council of 17 June 1999 on the charging of heavy goods vehicles for the use of certain infrastructures." L 187/42-50, Official Joumal of the European Communities, Luxembourg.

Federa! Highway Administration (FHWA), (1997). 1997 Federal highway cost allocation study, Final Report, U.S. DOT, Washington, DC.

Garvin, M. J. (2010). "Enabling development of the transportation pubiic-private partnership market in the United States." J. Constr. Eng. Manage., 10.1061/(ASCE)CO.1943-7862.0000122, 402-411.

Gomez, J. (2012). "Carga tarifaria y fiscal del transporte por carretera. Un análisis comparado entre Estados Unidos y Europa (in Spanish)." Master's thesis, Máster Universiturio en Sistemas de Ingeniería Civil, Unjversidad Politécnica de Madrid, Madrid, Spain.

Goodin, G., Baker, R. T., and Taylor, L. (2009), "Mileage-based user fces: Defining a path toward implementation. Phase 2: An assessment of in stitutional issues." Final Report, UTCM Project 09-39-07, University Transportation Center for Mobility, Texas Transportation Institute, College Station, TX.

Greene, D. L.+ Jones, D. W., and Delucci., M, (1997). The full costs and benefits of transportation, Springer, Ber]in.

Link, H. (2005). "Transpoit accounts-Methodological concepts and empirical results." J. Transp. Geogr., 13(1), 41-57.

MacKenzie, J. J., Dower, R. C., and Chen, D. T. (1992). The going rate: What it really costs to drive, World Resources Institute, Washington. DPC.

McMullen, B. S., Zhang, L., and Nakahara, K. (2010). "Distributional impacts of changing from a gasoline tax to a vehicle-mile tax for light vehicles: A case study of Oregon." Transp. Pol, 17(6), 359-366.

Mornis, H., and DeCicco, J. (1997). "Extent to which user fees cover road expenditures in the United States." Transportation Research Record 1576, Transportation Research Board, Washington, DC, 56-62.
National Surface Transportation Infrastructure Financing Commission (NSTTFC). (2009), Poying our way: A new framework for tronsportafion finance, Washington, DC.

National Surface Transportation Policy and Revenue Study Commission (NSTPRSC) (2007). Transportation for tomorrow, Washington, DC.

Oh, J. J., and Sinha, K. C. (2011). "Self-financing and distance-based highway pricing scheme: State highway system perspective." I. Infrastruct. Syst., $10.1061 /$ (ASCE)IS.1943-555X.0000050, 95-106.

Parry, I. W. H., and Small, K. A. (2005). "Does Britain or the United States have the right gasoline tax?"' Am. Econ. Rev, 95(4), 1276-1289.

Rall, J., Wheet, A., Farber, N., and Reed, J. B. (201 i). "Transportation govemance and finance, a 50 -state review of state legislatures and departments of transportation." Under the Guidance of the NCSL-AASHTO Joint Project Oversight Committee, A joint project of the National Conference of State Legislatures and the AASHTO Center for Excellence in Project Finance, National Conference of State Legislatures.

Sorensen. P., Wachs, M., and Ecola, L. (2010). "Systen trials to demonstrate mileage-based road use charges. contractor's final task report for NCHRP project 20-24(69) A." National cooperative highway research program, web-oniy document 161, Transportation Research Board of the National Academies, Washington, DC.

Standing Commitlee on Financing and Admiristration. (2007). Report on long-term financing needs for sufface transportation, AASHTO, Washington, DC.

Sundeen, M., and Reed. J. B. (2006). "Surface transportation funding: Options for states." At the direction of the NCSL Transportation Funding Parthership Committee and NCSL Transportation Committee, National Conf. of State Legislatures, National Conference of State Legislatures, Washingion, DC, Denver, CO.

Szimba, E., and Rothengatter, W. (2012). "Spending scarce funds more efficiently-including the pattern of interdependence in cost-benefit analysis." J. Infrastruct. Syst, 10.1061/(ASCE)IS.1943-555X.0000102, $242-251$

Transportation Reseatch Board. (2006). "The fuel tax and altematives for transportation funding." Special Rep. 285, Washington, DC.

U.S. DOT. (2012). "Refinements to DoT's management of the highway trust fund's solvency could improve the understanding and accuracy of shortfall projections." Rep. CR-2012-0\%, Audit Report, Office of Inspector General, Washingtor, DC.

Wachs, M. (2003). "Tmproving efticiency and equity in transportation fuance." Transportation Reform Series, Center on Urban and Metropolitan Policy, Brookings Institution Series on Transportation Reform, Washington, DC.

Wakeley, H. L., Griffin, W. M., Hendrickson, C., and Matthews, H. S. (2008). "Altemative transportation fuels: Distribution infrastructure for bydrogen and ethanol in Iowa." J. Infrastruct. Syst, 10.1061 (ASCE) 1076-0342(2008)14:3(262), 262-271.

Whitty, J. M. (2007) "Oregon's mileage fee. Concept and road user fee pilot program." Final Rep., Oregon Dept. of Transportation, Salem, OR, 